\title{
College English Teaching Reform from the Perspective of Applied Linguistics
}

\author{
Yan Zhang \\ Nanchang Institute of Science \& Technology, Nanchang City, Jiangxi \\ Province, 330108, China
}

\begin{abstract}
The application of applied linguistics in English teaching can make the students understand English more comprehensively and meticulously, and master the essence of the English language, which is not only the application effect of applied linguistics in the English teaching, but also the ultimate goal of English education in China. In this paper, based on the guidance of applied linguistics, we first summarized the basic connotation and development of applied linguistics, and then discussed the guiding significance of applied linguistics for English teaching reform. Finally, we put forward effective ways of English teaching reform under the guidance of applied linguistics.

Keywords: Applied linguistics; Connotation; College English; teaching reform
\end{abstract}

\section{Introduction}

Applied linguistics is the important subject content in the process of modern education development. Its close relationship with English teaching makes education experts in China find their fusion significance. The experts start the study on the application of applied linguistics in the English education. At present, certain achievements in the application of applied linguistics in English teaching has been achieved in China[1]. However, due to the relatively broad content of applied linguistics, the achieved research results are just the tip of the iceberg. The in-depth study of applied linguistics has profound significance for making applied linguistics play a better role in English education and other languages subject education. 


\section{Basic connotation and development of applied linguistics}

As for the essential significance of applied linguistics, applied linguistics can be divided into broad and narrow connotation. The broad connotation of applied linguistics refers to the linguistics is only applied to other scientific fields, and the narrow connotation of applied linguistics specifically denotes language teaching, especially the second language teaching. English is second language in China. Its status in language education system determines its internal relationship with the applied linguistics, which is main power to promote the educators to conduct applied linguistics and English teaching research. Although applied linguistics is summed up as the second language teaching in the narrow sense, but it should be noted that the traditional language teaching and applied linguistics is not the same thing. Applied linguistics is served as the proving ground of the second language education, which is one of the education modes of the second language practice. However, not all the second language practice education is a form of applied linguistics. Therefore, we must make a scientific distinction between applied linguistics and second language education[2].

Applied linguistics, proposed by Polish linguist Kurt inside (J. Baudouin de Courtenay, 1845-1929), can trace back its history as far as the second half of the 19 th century. At that time, it did not get attention. In the 1940s, applied linguistics appeared in linguistics academia in the United States, and quickly developed into an independent subject. The earliest applied linguistics courses was set at the University of Michigan in 1946. But applied linguistics didn't get a good development. The reason was that the college English teaching in China, to some extent, lacks attention to the applied education theory. Compared with the theoretical education content such as linguistics and psycholinguistics, the external language practice teaching such as language proficiency and teaching experience is more meaningful. Such education phenomenon of theory-neglecting, to a large extent, hindered the development of applied linguistics. Recently, with the transformation of our education concept and the continuous reform of teaching level, the importance of applied linguistics in English education has been widely promoted. In April 1999, Shanghai Foreign Language Education Press published an Oxford series of applied linguistics, which has become a milestone of the application of applied linguistics in English teaching in China.

\section{Guiding Significance of Applied Linguistics for English Teaching Reform}

\subsection{Clarify teaching pattern}

English is a basic subject of the education system in China, whose ultimate educational purpose is the improvement of English teaching effect via cultivating students' learning corpus consciousness and stimulating students' learning enthusiasm. From the perspective of English language discipline characteristics, 
oral English is the first basic content of English subject[3]. However, due to the differences between English and its teaching environment in China, oral English education in China is gradually conducted on the basis of written English teaching, which, to some extent, has violated the basic learning rules of the English language, and in turn affects the English language learning effect. Effective application of applied linguistics in the English education can determine the proportion of between the written and spoken English teaching, and extend it to the English curriculum to seek for promotion of the teaching effect by the teaching focus change.

At present, China's English education consists of two sections namely foundation and reinforcement. The foundation refers to listening, speaking, reading and writing, and the reinforcement refers to English translation. Listening, speaking, reading and writing are four teaching contents, and have their own difficulties. However, they also has certain internal mutual relationships. Therefore, the teaching implement must be based on different teaching methods. For example, although both the real-time translation and literary translation belong to the translation, there are some differences between them. Therefore, their schedules requirements should be distinguished in teaching in order to make sure the students can correctly grasp the method and main points of real-time translation and literary translation. In actual teaching, the emphasis of applied linguistics is based on students' specific goals. The teaching effect is guaranteed by making a practical and feasible teaching plan. Under this premise, if the students' understanding of the basic English knowledge is not too much, we should strengthen the students' oral English education so that they are able to speak English actively[4].

\subsection{Find teaching misunderstandings}

From the behaviors of the current English teaching, there are two main problems, which are misunderstandings of English education in China. The first one is too much emphasis on grammar and ignorance of the emotion. In the actual teaching process, a lot of teachers put emphasis on the grammar, pronunciation, and understanding. The analysis of the English text is by means of splitting the text into sentences, phrases, and even words. The analysis of the use of grammar and sentence structure occupies plenty of teaching time. This teaching behaviors of neglecting English language emotional effect make the students ignore the nature of the English language, and also forget the purpose of practical application of English study, which will weaken the teaching effect and dismiss students' interests in learning English.

The second one is error correction without analysis. In the process of the current English education, the majority of teachers can point out students' mistakes immediately when they find. However, no further analysis is conducted, which will make students know the wrong, but don't know where the wrong is so that the students will make similar mistakes. In terms of students' English learning, what teachers have to do is not only mistakes correction, but also timely analysis 
of students' errors. The deficiencies in English learning should be mastered and understood.

\section{Effective Ways of English Teaching Reform under the Guidance of Applied Linguistics}

\subsection{Study applied linguistics theory to guide teaching reform}

Research on applied linguistics theory to guide the teaching reform is one of the effective ways of deepening the reform of English teaching. English teaching reform and the active participation of teachers are inseparable. In the process of English teaching, English teachers should continue to strengthen the study of applied linguistics theory in the process of English teaching reform, vigorously develop the theory-learning of applied linguistics and related disciplines such as general linguistics, education, psychology, etc., and sum up experience in teaching English on the basis of the study of applied linguistics theory. In practice, the correct theory will be confirmed, and the false theory will be revised, which attributes to putting forward more scientific reform plan and using the theory to guide the teaching reform[5].

\subsection{Bring the role of teachers in English teaching reform into full play}

Bringing the role of teachers in English teaching reform into full play refers to strengthening the applied linguistics research in order to make every English teacher do some research related to English teaching and promote the need of English teaching reform under the condition of familiarity with applied linguistics. In the process of English teaching reform, Bringing the role of English teachers into full play is not only the objective requirement of English teaching reform for English teachers, but also the inherent requirement for English teachers to improve their professional quality For English teachers, As a designer, organizer and supervisor in teaching activities, it is very favorable for English teachers to conduct the applied linguistics and English teaching reform research work.

\subsection{Strengthen English "speak and write" ability training}

Strengthening English "speak and write" ability training is also indispensable in the process of applied linguistics and English teaching reform. With the continuous development of the social economy, China's international exchanges are increasingly frequent, and the traditional exam-oriented English teaching cannot meet the needs of the situation development. strengthening English "speak and write" ability, improving the students' English communication ability, and cultivating English talents suitable for the need of the society are the manifestation of integration development of applied linguistics and English teaching[6]. Therefore, in order to adapt to the needs of social development and satisfy the employer demand for English major students' English ability, we must 
strengthen the training of students' English communication ability in the process of teaching.

\subsection{Carry out English teaching reform via combining teaching practice}

English teaching reform involves in many factors. In the specific process of reform, English teachers should combine teaching practice to carry out English teaching reform. In the process of applying applied linguistics to guide the English teaching reform, the practical and realistic attitudes must be adopted towards the reform of college English teaching. Our teaching goal is to cultivate college students to have a certain listening, speaking, reading and writing abilities. In addition, the importance should be attached to cultivate students' innovation ability, practice ability and entrepreneurial spirit in higher education, which is mainly embodied in English teaching: to improve college students' English practical ability, broaden students' horizons, and make them know the world civilization and absorb nutrition from it[7].

\section{Conclusion}

In summary, applied linguistics is closely related to English teaching reform. In the process of English teaching reform, the application of applied linguistics in guiding the English teaching reform is a comprehensive system engineering, and has a long-term and complex nature. We should learn the theory of applied linguistics to guide the teaching reform, bring the role of teachers in English teaching reform into full play, strengthen English "speak and write" ability training, and carry out English teaching reform via combining teaching practice. Only in this way can we bring the advantages of applied linguistics into full play, and constantly improve the quality and level of English teaching.

\section{References}

[1] MA Rong. The transformation of college English teaching in the perspective of ecological linguistics. English Square, (09), pp.119-121, 2016.

[2] LI Dezhi. Research on tourism English teaching in the perspective of applied linguistics. Vocational and Technical, (10), pp.84-85, 2014.

[3] WANG Xianglin. College English teaching reform in the perspective of social linguistics. English Square (Academic Research), (04), pp.90-91, 2014.

[4] ZHANG Yanmi. College English teaching change in the perspective of ecolinguistic. Heilongjiang Education (Theory and Practice), (03), pp.44-46, 2014.

[5] WANG Zhengwei. Import teaching of English culture in the perspective of applied linguistics. Journal of Taiyuan Urban Vocational College, (11), pp.131$132,2012$. 
[6] CHEN Xiaoguang, ZHANG Fengxia. Import teaching of higher vocational English culture in the perspective of applied linguistics. Neijiang science and technology, (02), pp.174-176, 2012.

[7] LU Xiaoyong. Applied Llinguistics and college English teaching reform. Foreign Languages, (04), pp.39-44, 1999. 